\title{
REVIEW
}

\section{Translocation and reintroduction of native fishes: a review of bull trout Salvelinus confluentus with applications for future reintroductions}

\author{
Molly F. Hayes, Nolan P. Banish* \\ U.S. Fish and Wildlife Service, Klamath Falls Fish and Wildlife Office, Klamath Falls, OR 97601, USA
}

\begin{abstract}
Declines in freshwater biodiversity resulting from anthropogenic landscape and climate changes are occurring throughout North America. Reintroduction techniques including translocation, captive rearing, and artificial propagation are often used to create new populations, repatriate extirpated populations, or supplement declining populations. Bull trout Salvelinus confluentus, a salmonid endemic to the northwestern USA and southwestern Canada, experienced significant reductions in abundance and distribution throughout the 20th century, leading to its listing in the US as 'threatened' under the Endangered Species Act (ESA) in 1999. A variety of projects involving reintroduction or stocking of $S$. confluentus have occurred across the western USA and southwestern Canada. In this review, we summarize case studies involving the reintroduction of $S$. confluentus and use these case studies to develop recommendations and guidelines for future $S$. confluentus reintroductions. We recommend that the threats leading to the initial decline of $S$. confluentus must be adequately addressed prior to reintroduction. Further, translocation and reintroduction project documentation is essential for informing future projects.
\end{abstract}

KEY WORDS: Salvelinus confluentus - Bull trout - Reintroduction - Translocation - Captive rearing $\cdot$ Artificial propagation

\section{INTRODUCTION}

While freshwater covers less than $1 \%$ of the earth's surface, freshwater habitats support more than $10 \%$ of all known species and about $33 \%$ of vertebrate species (Strayer \& Dudgeon 2010). Freshwater habitats in North America are considered to support the greatest biodiversity and are also some of the most threatened aquatic ecosystems worldwide due to anthropogenic influences (Allan \& Flecker 1993, Ricciardi \& Rasmussen 1999, Abell et al. 2000). Anthropogenic threats to freshwater ecosystems include habitat degradation or destruction, water pollution, and flow modification (Dudgeon et al. 2006). The introduction of non-native species has also had significant negative and far-reaching impacts on freshwater ecosystems (Ricciardi \& MacIsaac 2011).

*Corresponding author: nolan_banish@fws.gov
The overexploitation and degradation of freshwater habitats in North America has led to declines in range and abundance of many freshwater organisms, including fish species (Jelks et al. 2008). An estimated $39 \%$ of all described fish species in North America were considered imperiled in 2008 and between 1989 and 2008 , there was a $92 \%$ increase in the number of imperiled freshwater and diadromous ichthyofauna in North America (Jelks et al. 2008, Strayer 2008). Many conservation projects have been undertaken to restore freshwater habitats and conserve or recover the species that depend on them; however, significant action is still needed to avoid further declines in freshwater biodiversity (Strayer \& Dudgeon 2010).

In an effort to recover imperiled freshwater species, the practice of propagating fish has been adapted for use as a restoration tool. While the majority of conser-

(C) Outside the USA the US Governemnt 2017. Open Access under Creative Commons by Attribution Licence. Use, distribution and reproduction are unrestricted. Authors and original publication must be credited.

Publisher: Inter-Research · www.int-res.com 
vation projects involving captive propagation have focused on terrestrial mammals and birds, some projects have focused on aquatic species, including fish, frogs, and mussels (Morell 2008, Strayer \& Dudgeon 2010). While reintroductions require considerable planning and follow through and may not be appropriate in all circumstances, they can be an important tool in the recovery of imperiled freshwater aquatic species.

\section{BACKGROUND INFORMATION ON SALVELINUS CONFLUENTUS}

Bull trout $S$. confluentus, members of the Salmonidae family and char subgroup, are native to western North America (USFWS 2015a). S. confluentus inhabit lakes and rivers, and may express either a resident or migratory life history strategy (USFWS 2015a). Within the migratory life history strategy, individuals may express fluvial, adfluvial, or amphidromous/anadromous tendencies. Fluvial individuals primarily reside in rivers while spawning and rearing in tributary streams. Adfluvial individuals primarily reside in lakes while spawning and rearing in streams. Amphidromous/anadromous individuals migrate between fresh and salt water (Cavender 1978, Fraley \& Shepard 1989, Rieman \& McIntyre 1993, McPhail \& Baxter 1996, WDFW et al. 1997, Goetz et al. 2004, Brenkman \& Corbett 2005, Downs et al. 2006, Jeanes \& Morello 2006, Brenkman et al. 2007). Resident and migratory forms often occur in sympatry and produce offspring that may express either life history strategy (Rieman \& McIntyre 1993, Brenkman et al. 2007, Homel et al. 2008). S. confluentus generally live at least $10 \mathrm{yr}$, and sometimes $20 \mathrm{yr}$ or more, reaching sexual maturity in 4 to 7 yr (McPhail \& Baxter 1996, Johnston et al. 2007, Al-Chokhachy \& Budy 2008). S. confluentus are iteroparous, meaning that they spawn multiple times throughout their lifetime, and may express either consecutive or alternate year spawning (Leathe \& Graham 1982, Fraley \& Shepard 1989, Pratt 1992, Rieman \& McIntyre 1996). Size, age at maturity, and life expectancy vary depending on habitat and life history strategy (USFWS 2015a).

$S$. confluentus have some of the most specific habitat requirements of any native salmonids in the northwestern USA (USFWS 2015a). Habitat require- ments are encompassed by the '4 Cs': cold, clean, complex, and connected habitat (USFWS 2015a). $S$. confluentus require water with temperatures generally below $15^{\circ} \mathrm{C}$, between 7 and $8^{\circ} \mathrm{C}$ for juvenile rearing, and between 2 and $4^{\circ} \mathrm{C}$ for egg incubation. $S$. confluentus also require low levels of suspended sediment and habitat with deep pools, overhanging banks, and large woody debris. In addition to habitat characteristics, there should be connectivity between spawning, rearing, foraging, migrating, and overwintering habitat (USFWS 2015a).

$S$. confluentus are widely distributed across the western coterminous USA, with populations in the Columbia and Snake River basins in Washington, Oregon, Montana, Idaho, and Nevada, the Puget Sound and Olympic Peninsula watersheds in Washington, the Saint Mary basin in Montana, and the Klamath River basin in south-central Oregon (Fig. 1) (USFWS 2015a). S. confluentus are also found in Canada and southeast Alaska and were historically present in the Sacramento River basin in northern California (USFWS 2015a)

$S$. confluentus abundance and distribution declined significantly throughout the 20th century, leading to the species' listing in 1999 as 'threatened' under the US Endangered Species Act (ESA) of 1973 (USFWS 2015a). Of the 4 S. confluentus populations in Canada, 2 are listed as being of 'special concern,' 1 is listed as 'threatened,' and 1 is listed as 'not at risk' by the Committee on the Status of Endangered Wildlife in Canada (Government of Canada 2016). At the time of

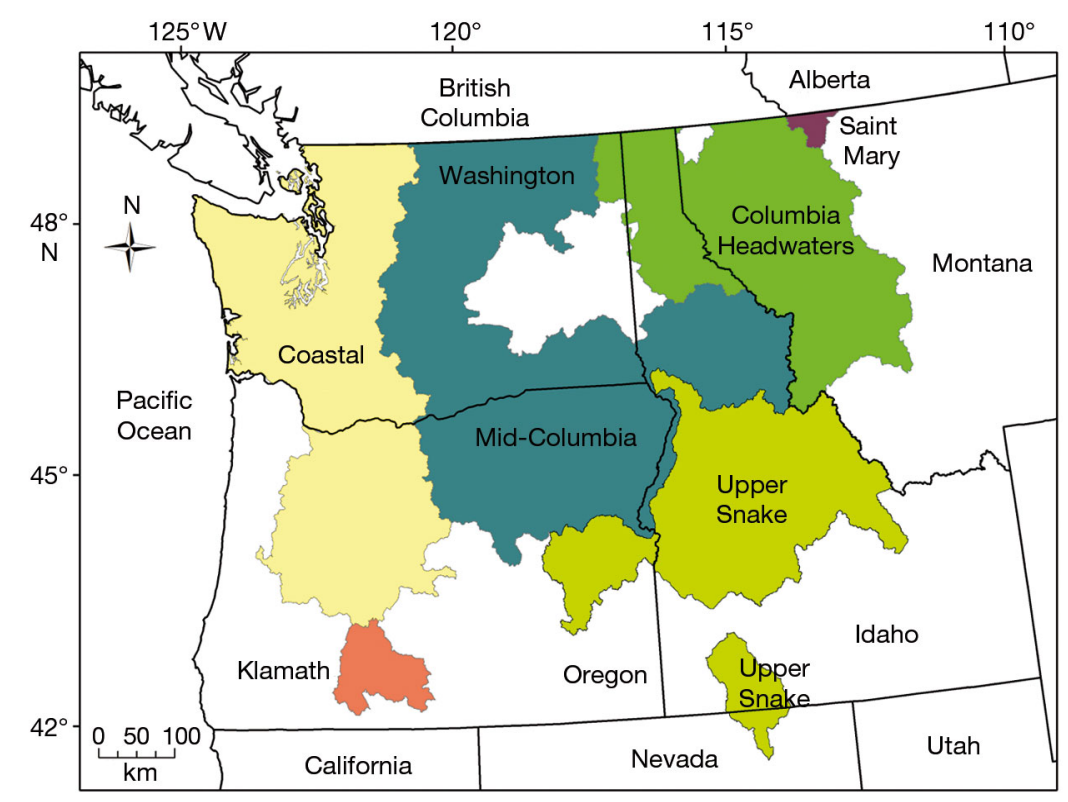

Fig. 1. Bull trout Salvelinus confluentus recovery units in the northwestern USA 
listing under the ESA in 1999, S. confluentus had been extirpated from an estimated $60 \%$ of their historic range, leaving populations localized and fragmented (Quigley \& Arbelbide 1997, USFWS 2015a). Conservation actions have been implemented in many areas, and $S$. confluentus are currently considered generally stable range-wide, with some populations increasing, some decreasing, and some remaining static, but with essentially no known change in general distribution (USFWS 2015a). The most recent short form status review completed in 2015, as well as a more thorough review in 2008, indicate that the threatened status is still appropriate (USFWS 2015a,b).

Declines in $S$. confluentus numbers and distribution are due to threat factors that vary significantly based on location (USFWS 2015a). Threats to S. confluentus include habitat loss and fragmentation, competition and hybridization with non-native fish species, and barriers to migration (USFWS 2015a,c). While anthropogenic climate change was not considered a threat when $S$. confluentus were listed in 1999, it has become clear that climate change impacts $S$. confluentus habitat and is an important conservation consideration (USFWS 2015a).

The US Fish and Wildlife Service's (USFWS) Recovery Plan for the Coterminous United States Population of Bull Trout (hereafter referred to simply as the 'Recovery Plan') establishes a strategic plan for the recovery of this ecologically important species (USFWS 2015a). The overall goal of the Recovery Plan is to restore $S$. confluentus populations through management of threat factors so the species no longer needs protection under the ESA (USFWS 2015a).

\section{TRANSLOCATION AND REINTRODUCTION OF SALVELINUS CONFLUENTUS}

Recovery of imperiled species often involves introduction, reintroduction, or supplementation. An introduction involves placing individuals in an area where that species was not historically distributed, whereas a reintroduction involves placing individuals in an area where that species was historically distributed but has been extirpated. Supplementation refers to the addition of individuals to extant populations. In the broader context of conservation, reintroductions are a method for restoring ecosystem function and species diversity to areas where extirpations have taken place (Ripple et al. 2014). The majority ofrecovery plans for threatened and endangered fish in the US call for introduction or reintroduction (Williams et al. 1988).
Introductions and reintroductions may involve translocation, captive rearing, or artificial propagation. Translocation involves capturing wild fish in the form of fertilized eggs, fry, juveniles, sub-adults, or adults and transporting them directly to a release site (Shively et al. 2007). In captive rearing, fertilized eggs, fry, or juveniles are captured in the wild and reared in a controlled facility prior to release (Shively et al. 2007). Artificial propagation differs from captive rearing in that the wild donor stock is held in a controlled facility and used to establish a captive broodstock program in which the progeny of the collected fish are released in the wild (Shively et al. 2007). For the purposes of this review, a successful project is defined as a project in which the overall trend in $S$. confluentus abundance is positive and a self-sustaining population seems to have been established according to the most recent data. An unsuccessful project is one in which the overall trend is negative and the establishment of a self-sustaining population seems unlikely. A project with mixed or unknown success is one in which either a small, but not self-sustaining, population has been established, or the outcome of the project is unknown.

The reintroduction of bull trout $S$. confluentus using translocation, captive rearing, artificial propagation, or some combination of these strategies will likely be required to restore $S$. confluentus populations in areas impaired by migratory barriers and lack of habitat connectivity (USFWS 2015a). The Recovery Plan states that reintroduction may be required to reestablish extirpated or supplement imperiled extant $S$. confluentus populations (USFWS 2015a,c). While the Recovery Plan specifies the use of genetically appropriate, pathogen-free individuals in reintroductions, instructions on the age, size, and condition of fish used and timing and techniques implemented are not provided (USFWS 2015a). Prior to future reintroductions of $S$. confluentus, it is essential to understand past reintroduction attempts and analyze their successes or failures. This review serves as a summary of past, current, and future attempts to reintroduce $S$. confluentus (collated in Tables 1-4), and considers the methods used and outcomes achieved in the context of future reintroductions.

\section{CASE STUDIES}

The following section provides an overview of Salvelinus confluentus translocation and reintroduction case studies, which are organized by projects that were successful, had mixed or unknown success, or 
194

Endang Species Res 34: 191-209, 2017

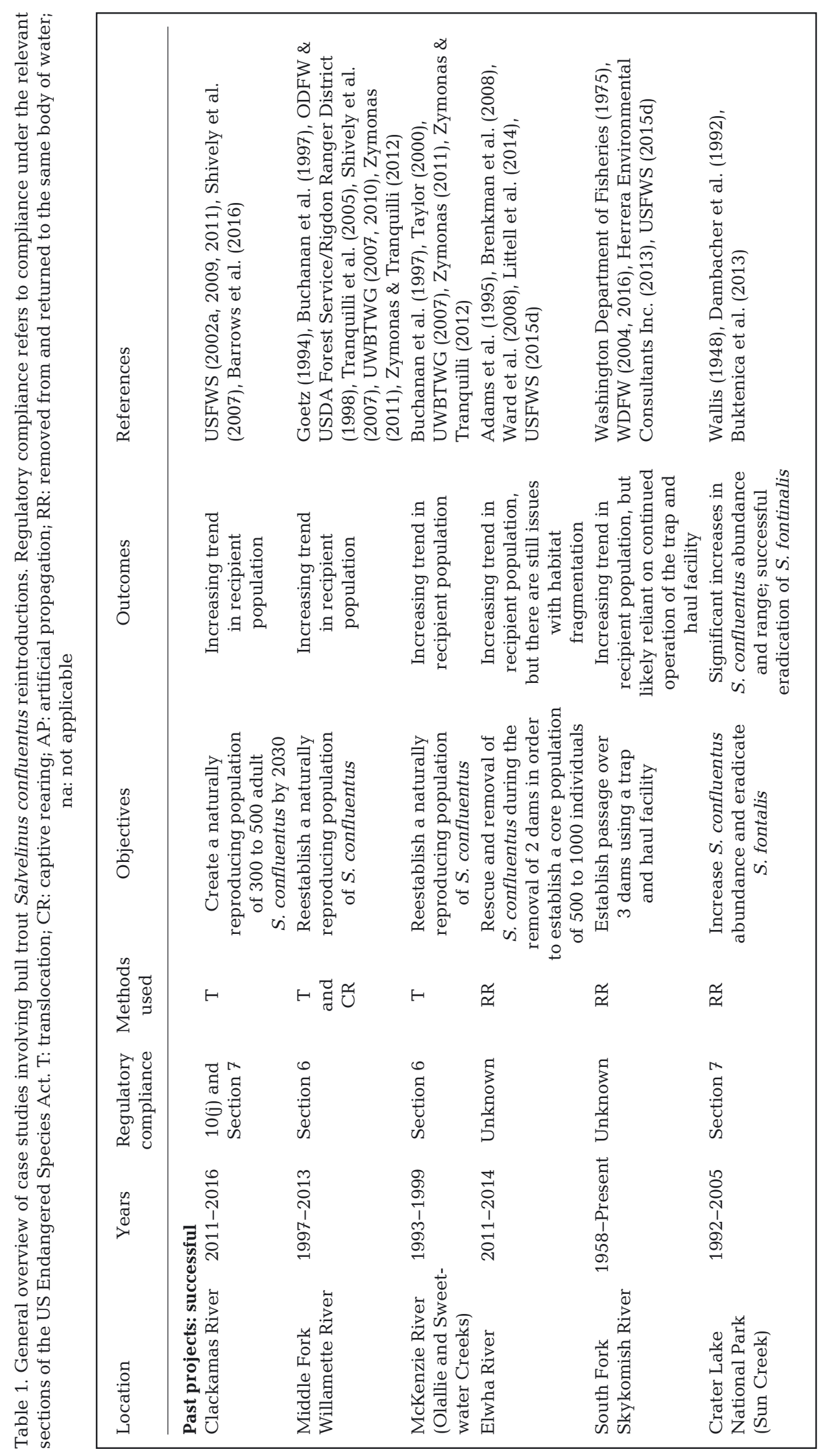




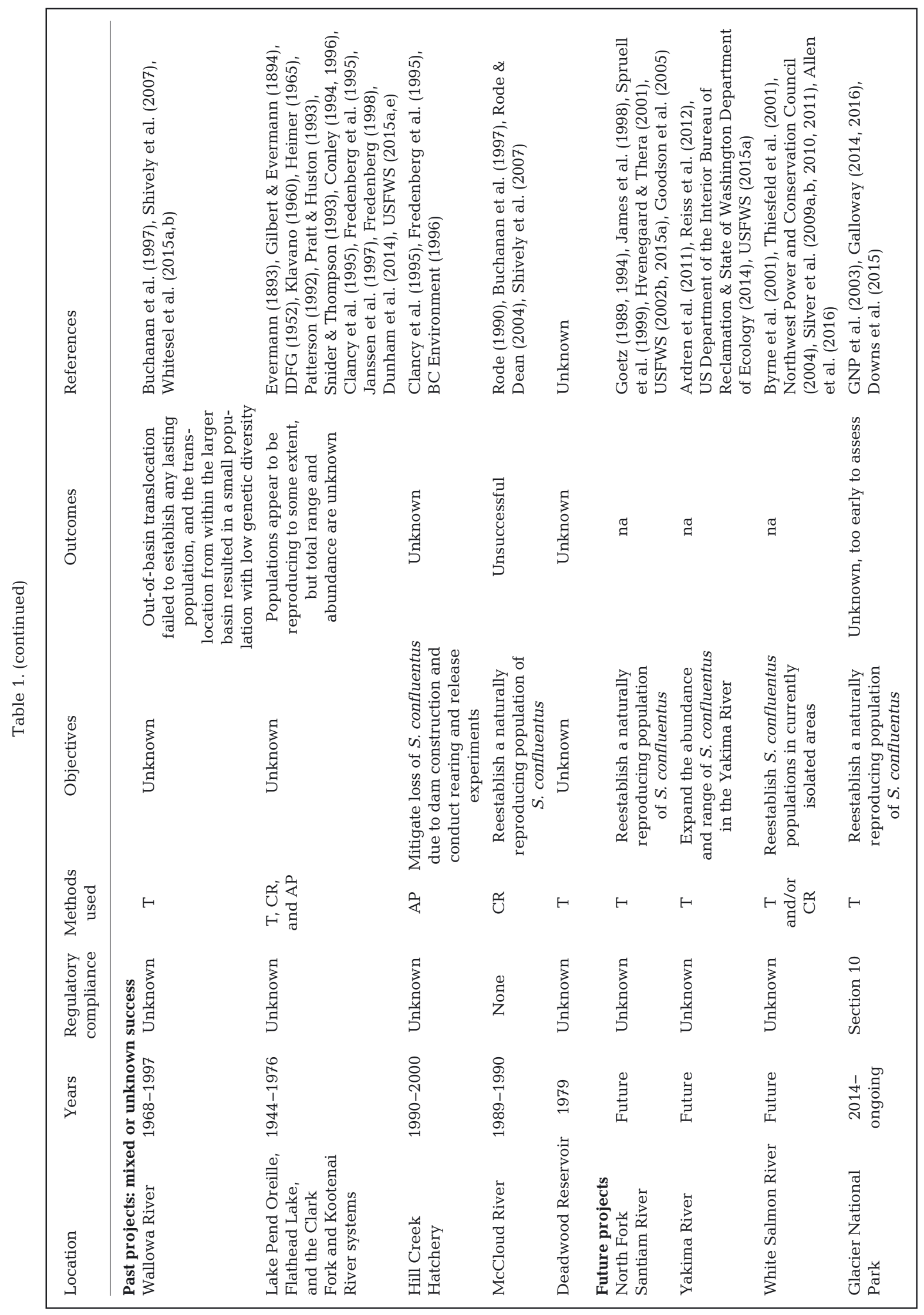


Table 2. Known reasons for declines in bull trout Salvelinus confluentus abundance and distribution, and restoration completed and in progress at case study locations. Reasons for decline include impacts from DD: dams and diversion; NF: nonnative fishes; $\mathrm{OH}$ : overharvest; FOM: forest management; AP: agricultural practices; and RDU: residential development and urbanization. Restoration activities include: FP: improved fish passage over dams, culverts, etc.; LWD: placement of large woody debris; AR: more restrictive angling regulations; DR: dam removal; NR: non-native fish removal; GA: gravel augmentation; PB: enhancement/reestablishment of prey base; DS: diversion screening; GR: general habitat restoration and enhancement; AU: some restoration completed, but actions unknown

\begin{tabular}{|c|c|c|c|}
\hline Location & Reasons for declines & $\begin{array}{l}\text { Completed } \\
\text { restoration }\end{array}$ & $\begin{array}{l}\text { Restoration in } \\
\text { progress }\end{array}$ \\
\hline \multicolumn{4}{|l|}{ Past projects: successful } \\
\hline Clackamas River & $\mathrm{DD}, \mathrm{OH}, \mathrm{FOM}, \mathrm{AP}, \mathrm{RDU}$ & FP & Unknown \\
\hline Middle Fork Willamette River & $\mathrm{DD}, \mathrm{NF}, \mathrm{OH}, \mathrm{FOM}, \mathrm{AP}, \mathrm{RDU}$ & LWD, GA, AR, FP & Unknown \\
\hline McKenzie River (Olallie and Sweetwater & Creeks) $\quad$ DD, OH, FOM & $\mathrm{AR}, \mathrm{FP}, \mathrm{GR}$ & Unknown \\
\hline Elwha River & DD & DR & AU \\
\hline South Fork Skykomish River & DD, NF present but not considered a threat & Unknown & Unknown \\
\hline Crater Lake National Park (Sun Creek) & NF & NR, DS & FP \\
\hline \multicolumn{4}{|l|}{ Past projects: mixed or unknown success } \\
\hline Wallowa River & NF, OH, FOM & None & None \\
\hline Lake Pend Oreille, etc. & $\mathrm{DD}, \mathrm{NF}, \mathrm{FOM}, \mathrm{AP}, \mathrm{RDU}$ & None & None \\
\hline Hill Creek Hatchery & DD & None & None \\
\hline McCloud River & $\mathrm{DD}, \mathrm{NF}, \mathrm{OH}, \mathrm{FOM}$ & AU & None \\
\hline Deadwood Reservoir & Unknown & Unknown & Unknown \\
\hline \multicolumn{4}{|l|}{ Future projects } \\
\hline North Fork Santiam River & DD, FOM, RDU & None & FP \\
\hline Yakima River & $\mathrm{DD}, \mathrm{NF}, \mathrm{OH}$ & None & FP, NR, PB, GR, DS \\
\hline White Salmon River & DD & DR & None \\
\hline Glacier National Park & NF & $\mathrm{DR}, \mathrm{GR}$ & NR \\
\hline
\end{tabular}

are planned for the future (Table 2). Case study headings reference the USFWS recovery unit where projects occurred, are underway, or will occur (Fig. 1). A case study reference of Other indicates the project occurred in Canada or is not included in a USFWS recovery unit. $S$. confluentus recovery units are the major units for managing recovery efforts by the USFWS.

\section{Clackamas River (Coastal Recovery Unit)}

While bull trout Salvelinus confluentus were once prevalent in the Clackamas River system, by 1963 they were essentially extirpated due to a variety of factors including the construction of dams and diversion, overharvest, forest management, agricultural practices, and residential development and urbanization (Shively et al. 2007). A reintroduction effort using translocated $S$. confluentus from the Metolius River, in a nearby basin, took place from 2011 through 2016 (USFWS 2009). The goal of the project was to create a naturally reproducing population of 300 to 500 adults by 2030 (Shively et al. 2007). Planning for the translocations involved the development of a feasibility assessment of $S$. confluentus reintro- duction to the Clackamas River system that determined that the factors leading to $S$. confluentus decline had been adequately addressed and reintroduction was feasible (Shively et al. 2007). In order to identify habitat appropriate for $S$. confluentus reintroduction within the Clackamas River system, a habitat suitability analysis was also conducted (Shively et al. 2007). The reintroduction effort involved translocation of $S$. confluentus and appears to have resulted in an increased number of $S$. confluentus present and increased spawning in the Clackamas River that may lead to the project's goal of 300 to 500 spawning adults by 2030 (Barrows et al. 2016). Monitoring of reintroduced $S$. confluentus in the Clackamas River sub-basin will continue for a minimum of $15 \mathrm{yr}$ and will hopefully continue to show high rates of survival and successful spawning (Barrows et al. 2016).

\section{Middle Fork Willamette River (Coastal Recovery Unit)}

The Middle Fork Willamette River in western Oregon historically supported a native population of 


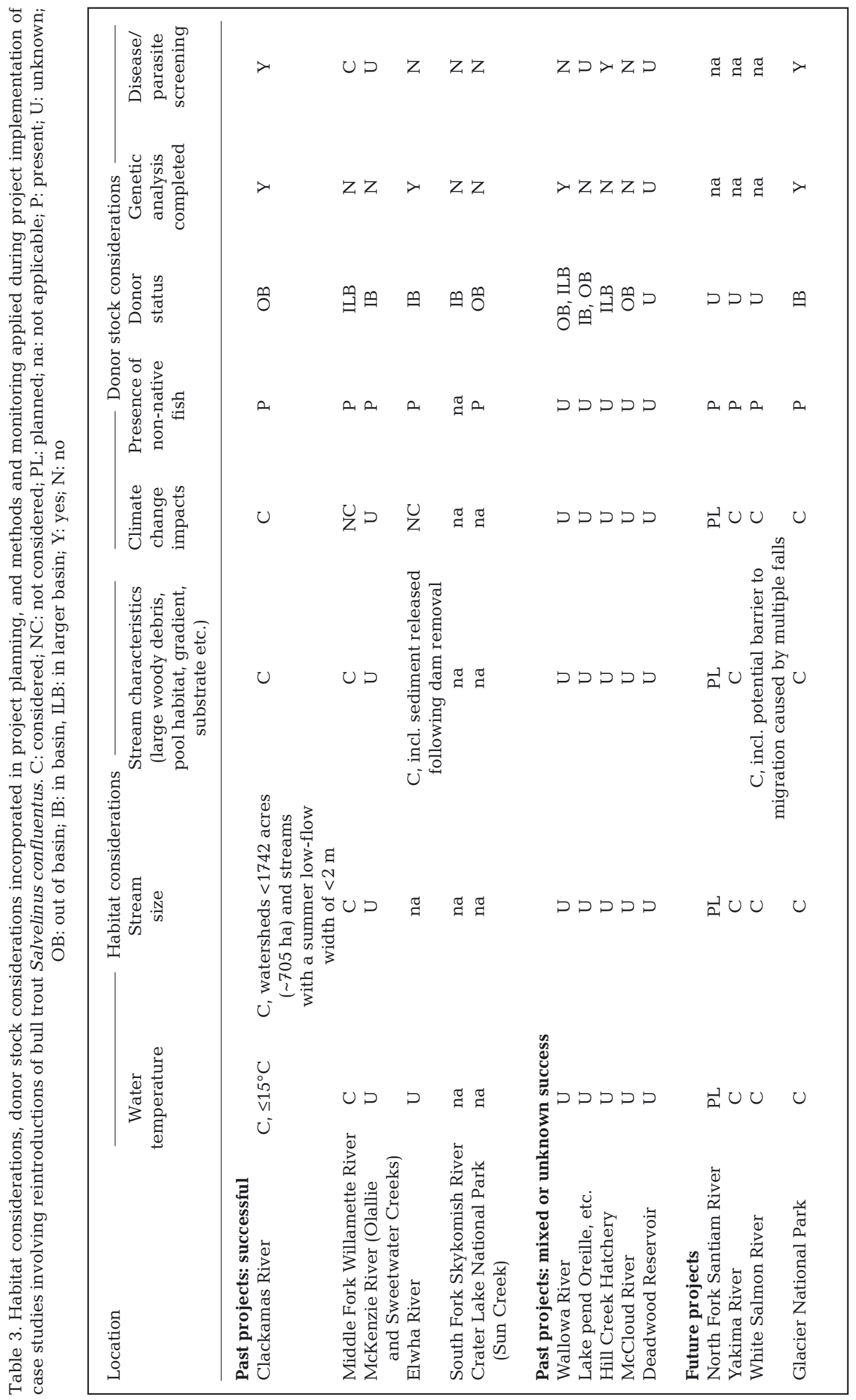


Table 4. Methods and monitoring used during project implementation of case studies involving reintroductions of bull trout Salvelinus confluentus. PL: planned; U: unknown; Y: yes; N: no; J: juvenile; SA: subadult; A: adult; M: minimal; $\times$ : times; AN: annual; CO: continual; na: not applicable

\begin{tabular}{|c|c|c|c|c|c|}
\hline \multirow[t]{2}{*}{ Location } & \multicolumn{3}{|c|}{ Methods } & \multicolumn{2}{|c|}{ Monitoring } \\
\hline & Number & Age/size & Frequency & $\begin{array}{c}\text { Donor } \\
\text { population }\end{array}$ & $\begin{array}{l}\text { Recipient } \\
\text { population }\end{array}$ \\
\hline \multicolumn{6}{|l|}{ Past projects: successful } \\
\hline Clackamas River & 2140 & $\mathrm{~J}, \mathrm{SA}, \mathrm{A}$ & AN & $\mathrm{Y}$ & $\mathrm{Y}$ \\
\hline Middle Fork Willamette River & 10408 & J, SA & $9 \times$ & $\mathrm{Y}$ & $\mathrm{Y}$ \\
\hline McKenzie River (Olallie and Sweetwater creeks) & 7047 & $\mathrm{~J}$ & $\geq 7 \times$ & $\mathrm{Y}$ & $\mathrm{Y}$ \\
\hline Elwha River & $\mathrm{U}$ & $\mathrm{J}, \mathrm{SA}, \mathrm{A}$ & $1 \times$ & $\mathrm{Y}$ & $\mathrm{Y}$ \\
\hline South Fork Skykomish River & $\mathrm{U}$ & $\mathrm{J}, \mathrm{SA}, \mathrm{A}$ & $\mathrm{CO}$ & M & M \\
\hline Crater Lake National Park (Sun Creek) & 480 & $\mathrm{SA}, \mathrm{A}$ & $1 \times$ & $\mathrm{Y}$ & $\mathrm{Y}$ \\
\hline \multicolumn{6}{|l|}{ Past projects: mixed or unknown success } \\
\hline Wallowa River & $>600$ & $\mathrm{SA}, \mathrm{A}$ & $\geq 2 \times$ & $\mathrm{N}$ & M \\
\hline Lake Pend Oreille, etc. & $>200000$ & $\mathrm{~J}$ & $\geq 15 x$ & $\mathrm{U}$ & $\mathrm{U}$ \\
\hline Hill Creek Hatchery & $>395299$ & $\mathrm{~J}$ & $\sim 11 \times$ & $\mathrm{U}$ & M \\
\hline McCloud River & 270 & $\mathrm{~J}$ & $1 \times$ & $\mathrm{N}$ & $\mathrm{Y}$ \\
\hline Deadwood Reservoir & 11000 & $\mathrm{~J}, \mathrm{SA}$ & $1 \times$ & $\mathrm{U}$ & $\mathrm{U}$ \\
\hline \multicolumn{6}{|l|}{ Future projects } \\
\hline North Fork Santiam River & $\mathrm{U}$ & $\mathrm{U}$ & $\mathrm{U}$ & na & na \\
\hline Yakima River & $\mathrm{U}$ & $\mathrm{U}$ & $\mathrm{U}$ & na & PL \\
\hline White Salmon River & $\mathrm{U}$ & $\mathrm{U}$ & $\mathrm{U}$ & na & PL \\
\hline Glacier National Park & 111 & $\mathrm{~J}$ & $\mathrm{AN}$ & $\mathrm{U}$ & $\mathrm{Y}$ \\
\hline
\end{tabular}

S. confluentus. S. confluentus populations in this fork of the river declined through the 20th century, and the last reliable observation of a $S$. confluentus in the Middle Fork Willamette River occurred in 1990 (Buchanan et al. 1997, Zymonas 2011). In an effort to reestablish a sustainable population of $S$. confluentus in the Middle Fork Willamette River, the Oregon Department of Fish and Wildlife (ODFW), the Willamette National Forest, the US Army Corps of Engineers, the Eugene Water and Electric Board, the USFWS, and other organizations came together to form the Upper Willamette Bull Trout Working Group (UWBTWG 2007). The UWBTWG conducted a project between 1997 and 2013 to restore habitat and reintroduce $S$. confluentus to the Middle Fork Willamette River (Zymonas \& Tranquilli 2012). This project involved annual translocations of $S$. confluentus between 1997 and 2005 from Anderson Creek, located in the nearby McKenzie River basin, to the Middle Fork Willamette River (Tranquilli et al. 2005, Zymonas 2011). Between 2007 and 2013, the UWBTWG altered its previous methods by implementing a captive rearing program in an attempt to increase survival of released $S$. confluentus (Zymonas \& Tranquilli 2012). Monitoring efforts are ongoing and indicate a positive trend in the recipient population and stable numbers in the donor population
(Shively et al. 2007, Zymonas 2011). The UWBTWG is also considering $S$. confluentus reintroductions in the North Fork Middle Fork Willamette River and Salmon and Salt Creeks downstream to Hills Creek Dam (Zymonas \& Tranquilli 2012).

\section{McKenzie River (Olallie and Sweetwater Creeks; Coastal Recovery Unit)}

The McKenzie River, a tributary to the Willamette River, is considered to be part of the same study area as the Middle Fork Willamette River. Buchanan et al. (1997) considered the $S$. confluentus populations in the mainstem McKenzie River and in 2 of its tributaries, Olallie and Sweetwater Creeks, to be of 'special concern,' while $S$. confluentus in the South Fork McKenzie River were considered 'high risk' by the UWBTWG (2007). Between 1993 and 1999, the UWBTWG transferred fry from Anderson Creek to Olallie and Sweetwater Creeks, all within the same basin, as part of the same project conducted on the Middle Fork Willamette River (UWBTWG 2007). Monitoring since translocations began in 1993 suggests that $S$. confluentus populations have been successfully reestablished in Olallie and Sweetwater Creeks (Zymonas \& Tranquilli 2012). 


\section{Elwha River (Coastal Recovery Unit)}

The Elwha River, a river flowing from the mountains of the Olympic Peninsula in Washington State west to the Pacific Ocean, historically supported a self-sustaining population of $S$. confluentus. Two dams were constructed within the mainstem of the Elwha River, i.e. the Elwha Dam in 1912, followed by the Glines Canyon Dam in 1927. While these dams created fish passage barriers resulting in isolated populations of $S$. confluentus within the mainstem of the Elwha River, in 2008, S. confluentus were still relatively prevalent in the upper watershed (Ward et al. 2008). Below the Elwha Dam, S. confluentus were much more restricted and the subpopulation was classified as 'depressed' by the USFWS (Ward et al. 2008). Between 2011 and 2014, the Elwha and Glines Canyon dams were removed and a rescue and removal plan was implemented to maintain $S$. confluentus populations in the Elwha River (Ward et al. 2008). No $S$. confluentus supplementation programs were established during this project. $S$. confluentus reestablishment relied on natural recolonization by rescued and removed fish and fish that remained in the river during dam removal (Ward et al. 2008). While dam removal is expected to have an overall positive impact on $S$. confluentus abundance and distribution, there are still threats facing $S$. confluentus in the Elwha River, including fish passage issues associated with dam removal sites, low instream flows from removal of water for municipal uses leading to seasonal lack of connectivity, and increased exposure to non-native fishes (USFWS 2015d). To reestablish self-sustaining populations of $S$. confluentus, additional habitat restoration will be completed to support recolonization (Ward et al. 2008). It is estimated to take between 3 and 5 generations (15 to $25 \mathrm{yr}$ ) or longer to establish a stable or increasing population (Ward et al. 2008).

\section{South Fork Skykomish River (Coastal Recovery Unit)}

Self-sustaining populations of $S$. confluentus and Dolly Varden S. malma (a species that was not distinguished from $S$. confluentus until the late 1970s) exist in the Upper Skykomish River basin of Washington State (WDFW 2004). In the South Fork Skykomish River, the Sunset, Canyon, and Eagle Falls create upstream fish passage barriers (WDFW 2004). In 1958, the Washington State Department of Fisheries, now the Washington Department of Fish and Wildlife (WDFW), constructed a trap and haul facility on the South Fork Skykomish River at Sunset Falls (WDFW 2004). The facility is co-managed by the WDFW and the Tulalip Tribes (WDFW 2016). This facility operates from July through December and moves fish from below the falls to release sites upstream of Sunset, Canyon, and Eagle Falls (Herrera Environmental Consultants Inc. 2013). This translocation over previously impassible obstacles allowed $S$. confluentus and $S$. malma to colonize $\sim 87 \mathrm{~km}$ (54 miles) of previously uninhabited river (Washington Department of Fisheries 1975, WDFW 2004). A recent proposal has been made to relocate the release sites to improve the habitat available to fish recovering from translocation (WDFW 2016). Few details are available on monitoring following the construction of the Sunset Falls trap and haul facility; however, in 2004, S. confluentus stock were considered to be healthy throughout the Skykomish River basin (WDFW 2004). Persistence of this population may be reliant upon continued operation of the trap and haul facility located at Sunset Falls (USFWS 2015d).

\section{Crater Lake National Park (Sun Creek; Klamath Recovery Unit)}

Until the mid-20th century, a healthy population of $S$. confluentus occupied lower Annie Creek and a portion of Sun Creek, 2 tributaries to the Wood River and Upper Klamath Lake (Wallis 1948). A 1989 survey of Sun Creek found that brook trout $S$. fontinalis occupied the entire creek, $S$. confluentus range had significantly contracted, and non-viable hybrids between $S$. fontinalis and $S$. confluentus were present (Dambacher et al. 1992). A project run by the National Park Service (NPS) to eradicate non-native $S$. fontinalis and increase numbers of native $S$. confluentus took place between 1992 and 2005. The Sun Creek project was not a reintroduction, but rather a re-establishment of $S$. confluentus and eradication of $S$. fontinalis. S. confluentus were removed from Sun Creek and held in a nearby fish-less stream or reared at a hatchery until large enough to conclusively identify, S. fontinalis were eradicated using manual and chemical methods, and $S$. confluentus were returned to the creek (Buktenica et al. 2013). Between 1989 and 2010, S. confluentus abundance in Sun Creek has increased from approximately 200 individuals to 2000 individuals, and $S$. confluentus distribution has increased from 1.9 to $11.2 \mathrm{~km}$ of stream (Buktenica et al. 2013). The successful reestablishment of $S$. conflu- 
entus in Sun Creek suggests that $S$. confluentus were limited by inter-specific competition with $S$. fontinalis (Buktenica et al. 2013). There are plans to continue this effort further downstream on Sun Creek while working to reconnect Sun Creek to the Wood River. Reintroductions of $S$. confluentus are also being considered in other creeks in the Klamath Recovery Unit (USFWS 2015a,c).

\section{Wallowa River (Mid-Columbia Recovery Unit)}

The Wallowa River, a river in northeastern Oregon that flows from the Wallowa Mountains into Wallowa Lake, supported a self-sustaining population of $S$. confluentus until they became extirpated in the 1950s (Buchanan et al. 1997, Whitesel et al. 2015a). This extirpation was likely due primarily to competition with non-native lake trout $S$. namaycush and redd superimposition by kokanee (sockeye) salmon Oncorhynchus nerka, a species that is also a prey source for S. confluentus (Shively et al. 2007). A variety of translocations took place between 1968 and 1997 that may be responsible for a small extant population of $S$. confluentus in the Wallowa River (Whitesel et al. 2015a, T. Whitesel pers. comm.). From 1968 through 1978, S. confluentus or S. malma were translocated from Alaska into the Wallowa River (Shively et al. 2007). In 1997, additional S. confluentus were translocated from the nearby Imnaha River to the Wallowa River (Shively et al. 2007). Monitoring between 1980 and 2013 indicated mixed success of these translocation projects (Buchanan et al. 1997, Whitesel et al. 2015b). The translocation of S. confluentus and/or S. malma between 1968 and 1978 was determined to be a failure (Buchanan et al. 1997). No monitoring followed the 1997 translocation of $S$. confluentus from the Imnaha River basin to the Wallowa River due to a lack of funding (Shively et al. 2007). Since 1997, there have been sporadic reports of $S$. confluentus observed and caught in the Wallowa River (Shively et al. 2007). Additional monitoring occurring between 2010 and 2013 involved the capture and genetic analysis of char in the Wallowa River (Whitesel et al. 2015b). These genetic results suggest that the 1997 translocation of S. confluentus from the Imhana River to the Wallowa River resulted in successful spawning and a small population with low genetic diversity (Whitesel et al. 2015b). While monitoring of $S$. confluentus will continue, there are currently no plans for future translocations of $S$. confluentus in the Wallowa River ( $\mathrm{T}$. Whitesel pers. comm.).

\section{Lake Pend Oreille, Flathead Lake, and other Montana and Idaho projects (Columbia Headwaters Recovery Unit)}

Lake Pend Oreille, Flathead Lake, and the Clark Fork and Kootenai River systems, part of the larger boundary system, historically supported populations of native $S$. confluentus (Pratt \& Huston 1993, Dunham et al. 2014). Development in the form of timber harvesting, grazing, mining, dam construction, and settlement as well as the introduction of non-native fish species have negatively impacted native $S$. confluentus populations (Evermann 1893, Pratt \& Huston 1993). The headwaters of the Clark Fork River system and portions of the Coeur d'Alene River system were contaminated by heavy metals that degraded historic S. confluentus habitat (USFWS 2015e). Despite these impacts, S. confluentus are present, often with a patchy distribution, in most of the major watersheds in the Columbia Headwaters Recovery Unit where they were historically distributed (USFWS 2015e). Between 1944 and 1976, Montana Department of Fish, Wildlife and Parks conducted a variety of projects to stock $S$. confluentus or $S$. malma into the Clark Fork and other river systems in Montana (Pratt $\&$ Huston 1993). These projects involved the translocation, captive rearing, and artificial propagation of multiple fish species. Fish were moved between river systems from areas as distant as Alaska, leading to introduction of new genetic material and hybridization between species (Pratt \& Huston 1993). Many of the stocking projects that occurred from 1944 to 1976 were not closely monitored, and few data exist on project outcomes. It appears that the populations of $S$. confluentus in Lake Pend Oreille are stable and robust, while the majority of other populations in the Columbia Headwaters Recovery Unit have abundances well below historic levels or have been extirpated (USFWS 2005). Local populations in the Lower Clark Fork River are reproducing to some extent; however, overall abundance is low and there are no known self-sustaining populations between Albeni Falls Dam and Boundary Dam (Pratt \& Huston 1993, Dunham et al. 2014). Recently, the USFWS has begun the planning process for a project to increase $S$. confluentus population sizes and ranges in the Clark Fork River system through establishing connectivity past dams, improving habitat, and potentially translocating fish (Dunham et al. 2014, USFWS 2015e). A future $S$. confluentus reestablishment plan will likely address existing threats and suggest actions to reestablish a self-sustaining population of $S$. confluentus (USFWS 2015e). 


\section{Hill Creek Hatchery (Other)}

In British Columbia (BC), Canada, S. confluentus are considered a 'blue-listed' species by the BC Conservation Data Centre, a similar classification to their threatened status under the ESA in the USA. As part of a mitigation project to address the loss of $S$. confluentus as a result of the construction of Keenleyside and Revelstoke Dams on the Columbia River, the Kootenay Trout Hatchery began experimental work with $S$. confluentus in the early 1980s (Clancy et al. 1995). The goal of the project was to compensate for approximately $4000 \mathrm{~S}$. confluentus eliminated due to dam impacts (Decker \& Hagen 2008). This project was transferred to the Hill Creek Hatchery located near Upper Arrow Lake in the headwaters of the Columbia River basin where it continued from 1990 through 2000 (Fredenberg et al. 1995, BC Environment 1996). Fish propagated as part of this project were spawned from wild adults caught each year, and juvenile fish resulting from the program at Hill Creek Hatchery were scatter-planted in tributaries to the Columbia River (Fredenberg et al. 1995, BC Environment 1996). Initial monitoring to evaluate the survival of released juvenile $S$. confluentus was inadequate to assess outcomes; however, a study conducted from 2004 to 2006 provided more information on whether the Hill Creek Hatchery S. confluentus mitigation program successfully reached its goal of compensating for $S$. confluentus loss in the Upper Columbia River basin due to dams (Clancy et al. 1995). This 3 yr study assessed $S$. confluentus habitat, abundance, and distribution in tributaries to Arrow Lake Reservoir and found that there are approximately 900 redds annually in all tributaries, with the majority of redds in 2 relatively large glacial systems (Decker \& Hagen 2008). Additional conservation measures will be needed to protect and restore $S$. confluentus habitat and encourage a selfsustaining population in Arrow Lake Reservoir and its tributaries (Decker \& Hagen 2008).

\section{McCloud River (Other)}

In California, S. confluentus were historically only native to the McCloud River in the northern region of the state (Rode 1990). The McCloud River is a major tributary of the Sacramento River, flowing from mountainous regions in northern California south to Shasta Reservoir (Rode 1990). S. confluentus appeared to be extirpated from the river by the late 1970 s, with the last confirmed $S$. confluentus sighting in 1975 (Rode 1990). S. confluentus extirpation in the McCloud River was likely due to a variety of anthropogenic factors including angling mortality, introduction of non-native salmonids, impacts from mining, road building, and timber practices, and effects of dam construction (Rode 1990). Attempts to reintroduce $S$. confluentus to the McCloud River have been made; however, little documentation is available and it appears that the majority of these projects occurred without any state or federal regulatory compliance. In 1989, more than 60 adult $S$. confluentus native to the Sprague River basin in the Klamath Recovery Unit were captured and spawned at the ODFW Klamath Hatchery (Shively et al. 2007). The resulting juveniles were stocked into the McCloud River in the spring of 1990 (Shively et al. 2007). The $S$. confluentus released in the McCloud River in 1990 were monitored for 5 yr before the project was deemed a failure and monitoring was terminated (Buchanan et al. 1997). Introduction of a relatively small number of $S$. confluentus on a single occasion may have contributed to the lack of success. While $S$. confluentus are believed to be extirpated from the McCloud River, if any fish are found, the California Department of Fish and Game plans to pursue an artificial propagation program in an attempt to recover the population of $S$. confluentus (Rode \& Dean 2004).

\section{North Fork Santiam River (Coastal Recovery Unit)}

S. confluentus were historically distributed in both the North and South Santiam River basins (Goetz 1994). The last $S$. confluentus sighting in the North Santiam River basin occurred in 1945, and in 1953 the last $S$. confluentus was observed in the South Santiam River basin (Goetz 1989). Human activities including forest management practices, residential development, and the construction of dams and diversion have led to the removal of streamside vegetation, increases in water temperature, loss of in-stream large woody debris, increased erosion and suspended sediment, and additional barriers to migration (USFWS 2015a). The North Fork Santiam River, the section of the Santiam River with the greatest historical presence of $S$. confluentus, is considered a candidate location for reintroduction using translocation (USFWS 2002b). A translocation project could be modeled after similar projects that have taken place in the nearby Clackamas and Middle Fork Willamette rivers 
(USFWS 2015a). A feasibility assessment will include more details on considerations and plans for an $S$. confluentus reintroduction.

\section{Yakima River (Mid-Columbia Recovery Unit)}

The Yakima Bull Trout Action Plan Working Group (YBTAPWG) is in the process of planning a project to expand the abundance and range of $S$. confluentus in the Yakima River in Washington State (Reiss et al. 2012). The Yakima River was historically connected to the Snake River and Upper Columbia River basins; however, dam construction has significantly decreased connectivity (Ardren et al. 2011, Reiss et al. 2012). Many of the same threats facing $S$. confluentus in other western river systems are present in the Yakima River, including habitat fragmentation and angling mortality (US Department of the Interior Bureau of Reclamation \& State of Washington Department of Ecology 2014). The Bull Trout Task Force (BTTF), a collaborative of multiple organizations with the goal of conserving and restoring $S$. confluentus populations, plans to address the threats facing $S$. confluentus in the Yakima River basin and to continue monitoring $S$. confluentus abundance and distribution (US Department of the Interior Bureau of Reclamation \& State of Washington Department of Ecology 2014). Translocation and/or supplementation of $S$. confluentus may be used as a tool to reach the project goals (US Department of the Interior Bureau of Reclamation \& State of Washington Department of Ecology 2014). The YBTAPWG conducted a threat analysis to determine threats, develop a plan to address threats, and assess habitat suitability for $S$. confluentus (Reiss et al. 2012). The BTTF plans to address the major threats to $S$. confluentus in the basin while also conducting a feasibility assessment to consider whether translocation and/or supplementation is reasonable (Reiss et al. 2012). This feasibility assessment should be completed by 2017 (Reiss et al. 2012).

\section{White Salmon River (Mid-Columbia Recovery Unit)}

The White Salmon River flows from the south side of Mt. Adams to the Columbia River in Washington State. S. confluentus were likely present in the river prior to the construction of Condit Dam in 1913, a run-of-the-river project with no fish passage struc- tures (Northwest Power and Conservation Council 2004, Allen et al. 2016). Two S. confluentus were sighted in the White Salmon River above Condit Dam between 1991 and 2011; however, recent surveys have failed to detect the species and it is believed that only a very small number, if any, $S$. confluentus remain in the river (Byrne et al. 2001, Thiesfeld et al. 2001, Silver et al. 2009a,b, 2010, 2011). Condit Dam was breached in 2011 and completely removed in 2012, leading to increased habitat availability for $S$. confluentus and the deposition of spawning gravel downstream of the dam site (Allen et al. 2016). The White Salmon Working Group, a group comprised of the USFWS, Yakima Nation, WDFW, National Marine Fisheries Service, the US Forest Service, PacifiCorp, and USGS, has analyzed $S$. confluentus distribution and habitat in the White Salmon River and may develop a reintroduction plan in the future (Silver et al. 2011, Allen et al. 2016).

\section{Glacier National Park (Columbia Headwaters Recovery Unit)}

While $S$. confluentus were historically widespread in the North and Middle Forks of the Flathead River in Glacier National Park (GNP), the introduction of non-native $S$. namaycush to the basins in the early 20 th century led to significant declines in $S$. confluentus abundance and distribution (GNP et al. 2003). The Montana Cooperative Fishery Research Unit, US Geological Survey (USGS), NPS, and USFWS conducted an assessment of $S$. confluentus translocation potential in GNP (Galloway 2014, Galloway et al. 2016). The $S$. confluentus translocation process has begun, although the majority of this project is still in the planning process and has yet to be implemented (USFWS 2005, Galloway et al. 2016). Potential recipient sites were evaluated using a scoring framework that included the ability of the site to support translocated fish, possible negative impacts of a translocation on native aquatic biota, and the availability of within-basin donors (USFWS 2005, Galloway 2014). In 2014, in accordance with translocation guidelines, translocations began at the site considered to be best in terms of habitat and isolation from non-native trout (Downs et al. 2015). In 2014 and 2015, translocations occurred upstream of a barrier in Grace Lake, a location in the same drainage as the source population. While it is too early to assess the success of the 2014 and 2015 translocations, future work in GNP will focus on continuing within-basin translocations and monitoring of translocated S. confluentus (Gal- 
loway et al. 2016). Supplementation of translocated populations is planned and will likely utilize a second nearest neighbor source due to limited abundance of the original donor stock.

\section{TRANSLOCATION GUIDELINES AND RECOMMENDATIONS}

As the varied outcomes of the case studies included in this review suggest, thorough guidelines and recommendations should be considered prior to implementing a project involving translocation, captive rearing, or artificial propagation to reduce risk and maximize benefit. While categorizing projects as complete successes or failures is problematic because it imposes an artificial end date on the ongoing process of species recovery, all projects achieve a form of success in the information they can provide to future efforts (Jachowski et al. 2016). The varying methods used and outcomes achieved in the case studies of bull trout Salvelinus confluentus reintroductions reviewed here shed light on what attributes lead to more or less favorable outcomes. This information has been incorporated with the 'Guidelines for propagation and translocation for freshwater fish conservation' George et al. (2009) and is summarized in this section.

The first step to determining the necessity and appropriateness of a reintroduction involving translocation, captive rearing, or artificial propagation is to complete surveys to assess the status of existing populations (George et al. 2009). In species with sparse numbers, it may be extremely difficult to detect individuals; however, the development of environmental DNA testing may make this easier in the future. Detecting existing individuals is imperative when projects involve lethal treatment of sections of stream to eradicate non-native fish (George et al. 2009). Second, the historic range of the species should be determined (George et al. 2009). Given the changing climate and warming water temperatures, $S$. confluentus may need to be reintroduced beyond its historic range. Introducing a trout species beyond its historic range may have significant impacts on other species and should be carefully considered before beginning a project involving translocation. On the South Fork Skykomish River, S. confluentus were translocated above a natural barrier to a stretch where S. confluentus were not historically distributed (WDFW 2004). Fishless bodies of water often support unique species that may be adversely impacted by the introduction of fish (Muhlfeld et al.
2011). Trout prey on aquatic invertebrates, thereby directly impacting invertebrate populations (Luecke 1990, Schindler \& Parker 2002). Trout also have cross-boundary trophic impacts on other species that rely on invertebrates, including ducks and passerine bird species (Elmberg et al. 2010, Epanchin et al. 2010). Trout may also reduce duck populations through predation of ducklings (Elmberg et al. 2010). Third, the proposed habitat for reintroduction should be considered for suitability and any necessary habitat restoration should be completed (George et al. 2009).

Many of the case studies summarized in this review utilized a variety of intensive survey techniques to determine the status of existing $S$. confluentus. In the Middle Fork Willamette River, ODFW used repeated electrofishing and snorkel surveys in an attempt to detect $S$. confluentus prior to beginning a reintroduction project. While a variety of case studies attempted to delineate the historic distribution of S. confluentus, this was a difficult process in many areas due to a lack of complete and accurate documentation. Almost all case studies considered the suitability of habitat for S. confluentus to some extent. Habitat suitability assessments generally considered attributes including water temperature, the availability of complex habitat with suitable spawning gravel availability, the presence of a prey base, and the potential for competition and hybridization with non-native trout species. Many projects also involved significant habitat restoration prior to $S$. confluentus reintroductions.

A team of stakeholders should assemble to obtain necessary permits. Regulatory considerations include determining a means for ESA coverage and obtaining transportation, scientific take, and recovery permits from appropriate agencies. Before beginning a project, the USFWS policy regarding controlled propagation requires a review of actions in the Recovery Plan, a draft environmental assessment, the presentation of the environmental assessment in the Federal Register for public comment, incorporation of comments from the public, and the finalization of the environmental assessment. Geneticists and other experts should be consulted prior to project planning to obtain advice on donor stock source, number, and frequency of stocking (George et al. 2009).

Many of the case studies included in this review either did not obtain proper regulatory authorization or means of regulatory compliance were not documented. In some instances, a lack of authorization resulted from projects occurring prior to current regulatory mandates including those required by the 
ESA, or they occurred in Canada. Some of the projects that did report regulatory compliance under the ESA include the Clackamas River, which utilized Section 10(j) and Section 7, the Middle Fork Willamette River, which used a Section 6 agreement, Sun Creek, which used a Section 7 consultation, and GNP, which used the Section 10 recovery permit. The projects in which regulatory compliance was reported did not document reasons for selecting the regulatory allowance that was used. For future projects, it is critical that regulatory approval is obtained and adequately recorded to ensure that projects comply with laws and regulations and can be used as models for subsequent projects.

The number, age, and genetic composition of translocated fish should be carefully considered to minimize the impact on the donor population and maximize the benefit to the recipient population. Enough individuals should be translocated to ensure genetic diversity in the recipient population, but not so many as to cause undue risk to the donor population. The USFWS and other organizations consider a threshold of between 800 and 1000 spawning adult $S$. confluentus optimal to avoid inbreeding depression and ensure long-term persistence (USFWS 2002b, 2011, Reiss et al. 2012). While an abundance of 800 to 1000 spawning adults may be ideal, many extant wild populations of $S$. confluentus have persisted for long periods of time with numbers much lower than this threshold. Although younger fish have a lower likelihood of survival, their removal also has less of an impact on the donor population. This trade-off should be considered when selecting an age, or range of life stages, for translocated individuals. The survival of fertilized eggs or juvenile fish may be increased through captive rearing prior to release, although there are domestication issues to consider. In addition to ensuring genetic variation by selecting an appropriate number of fish to translocate, the genetic composition of the source population should match that of the historic, extirpated population as closely as possible. Maximizing the genetic diversity of donor stock in order to minimize the possibility of extirpation due to narrow genetic diversity may also be an important consideration.

The most consistently reported characteristic of projects included in the case studies portion of this review was the number of fish translocated; however, few reports provided justification for selected numbers. Many projects, including those on the Clackamas, Elwha, and Skykomish Rivers, carefully considered donor stock to minimize genetic differences between extirpated $S$. confluentus populations and reintroduced fish. Both the Clackamas and Elwha River projects involved the collection of DNA samples for future genetic analysis. The McCloud River project provides an example of how an inappropriate number of fish translocated and frequency of translocations can contribute to the failure of a project. Low numbers of fish translocated and only a single translocation event likely led to the failure to reestablish a population of $S$. confluentus in the McCloud River. Source and number of fish translocated should be carefully considered in the context of the specific characteristics of a project to achieve the best possible outcome.

If a project requires artificial propagation or captive rearing, the facility used should be as similar to the wild as possible to minimize the risk of domestication and subsequent declines in survival when returned to the wild (George et al. 2009). Fish should be handled as little as possible to minimize stress.

Few of the case studies included in this review involved artificial propagation or captive rearing, and those that did generally failed to document methods used. Projects involving translocation of fish should also prioritize careful handling of fish. The Clackamas River project reduced stress associated with handling and transport by adding a mild anesthetic to transport water (Shively et al. 2007).

Recipient habitat conditions should be considered in order to maximize survival of translocated fish (Galloway et al. 2016). A habitat suitability analysis should look at stream temperature, distribution of large woody material, pools, and spawning substrate, road density, land allocation, anticipated future conditions, and distribution, size, and connectivity of appropriate habitat (Shively et al. 2007). Other ecological components should also be analyzed, including the availability of a food source and the presence of non-native fish (Shively et al. 2007). Because translocation between watersheds always has the potential to introduce fish pathogens, fish must be screened for diseases and parasites prior to translocation (USFWS 2015a). Before translocation begins, the factors leading to the initial decline of $S$. confluentus in the area must be adequately addressed (Shively et al. 2007). Fish translocated to habitats in which the factors leading to the initial decline of the population have not been significantly mitigated or eliminated have a very low probability of long-term survival (George et al. 2009). Projects with a low likelihood of resulting in a self-sustaining population waste resources and may negatively impact donor populations.

A number of the well-documented case studies included some form of habitat analysis and restoration 
prior to release, although many projects did not include actions to mitigate the factors leading to the initial decline of $S$. confluentus. These projects included those on the Clackamas, Middle Fork Willamette, Wallowa, McCloud, and North Fork Santiam Rivers. A common theme of the projects that included habitat analysis and restoration was the eradication of nonnative trout species in preparation for $S$. confluentus reintroductions. Another primary threat addressed prior to translocation in many case studies was the removal of dams that created barriers to $S$. confluentus. While recipient habitats should be adequate for $S$. confluentus release, as in the case of the McCloud River project, reintroductions can begin in areas already restored while planning and implementation of restoration is carried out in more degraded habitats. All factors leading to the initial decline of $S$. confluentus should be addressed prior to a translocation.

Translocated populations should be monitored to assess survival, growth, condition, movement, and genetic diversity of individuals (George et al. 2009). Evaluation methods may involve a variety of survey strategies as well as tracking using passive integrated transponder (PIT) tags and PIT arrays and radio telemetry. Long-term monitoring should be used to evaluate translocation projects, and projects should be adaptively managed based on monitoring results (George et al. 2009).

The Clackamas River, Middle Fork Willamette River, and Sun Creek projects all involved postreintroduction monitoring. Monitoring methods used in these projects included the use of PIT arrays, snorkel surveys, fish traps, minnow traps, infrared counters, and time-lapse video. On the Clackamas River, monitoring results from the first few years of reintroductions were used to adapt and improve methods for subsequent reintroductions. A variety of factors likely contributed to the failure to monitor a number of projects. For example, a lack of funding resulted in failure to monitor following $S$. confluentus reintroduction to the Wallowa River.

Sharing projects with the public may lead to broader positive impacts. Where appropriate, projects should be shared with private landowners, commercial and recreational anglers, elected and nonelected officials, and the general public (George et al. 2009).

A few projects involved the public in the form of raising public awareness to decrease $S$. confluentus angling mortalities; however, no projects reported public involvement beyond this. Public involvement may not have been documented or these projects may not have been shared with the public.
Recording the specific methods and results of projects involving translocation, captive rearing, or artificial propagation is essential to understanding biogeography and genetic distribution of $S$. confluentus while also informing future projects (George et al. 2009). When warranted, results should be published in professional journals.

Very few of the projects included in this review adequately documented the methods used and outcomes achieved. For example, the section on Lake Pend Oreille, Flathead Lake, and other Montana and Idaho projects mostly included projects with essentially no documentation beyond the recipient location and number of fish translocated. Additionally, no documentation of outcomes was available for the project at the Hill Creek Hatchery. Many of the projects with minimal documentation occurred 50 or more years ago when documentation may not have been deemed important. However, thorough documentation of projects involving translocation is absolutely essential to future management of populations involved in those projects and to the development of other similar projects.

While translocation, captive rearing, and artificial propagation can be useful tools in species recovery, there are a variety of advantages, disadvantages, and ethical considerations associated with these practices. Artificial propagation can lead to a large number of individuals stocked with a reduced risk to the donor population; however, it is often an expensive process that may result in the loss of genetic diversity and a potential increase in the frequency of deleterious recessive alleles in the translocated population (Shively et al. 2007). Captive rearing may result in high abundance and survival of stocked individuals as well as the potential to implant PIT tags when fish reach an appropriate size, but may also be expensive and can result in disease transmission, loss of individuals due to malfunction of controlled facilities, and a possible increase in the frequency of deleterious recessive alleles (Shively et al. 2007). Because translocation is the least expensive of these methods and has the lowest possibility for loss of genetic variability and ecological diversity, it is often used to restore diminished or extirpated fish populations (Shively et al. 2007). Translocation does, however, have the highest risk to the donor population by decreasing population sizes (Shively et al. 2007).

Any project involving the transportation of fish from one location to another may have significant negative consequences (Brignon 2016). While failed reintroductions may inform future projects, they waste resources, jeopardize extant populations being 
used as donors, and negatively impact public perception of conservation efforts (Jachowski et al. 2016). Past translocation projects completed without appropriate consideration for potential risks have resulted in negative outcomes including the introduction of invasive, non-native species and the eradication of native species (Mueller \& Hellmann 2008, Minteer \& Collins 2010, Ricciardi \& Simberloff 2009). Designating an appropriate range for reintroduction can also be difficult given the often insufficient, inaccurate, or nonexistent documentation of historic ranges as well as ecosystem changes resulting from anthropogenic impacts (Jachowski et al. 2016). A proposed translocation of $S$. confluentus upstream of a natural barrier in the Selway Wilderness has drawn attention to the question of whether translocations within designated wilderness areas are applicable under the Wilderness Act. The USFWS will utilize the National Environmental Policy Act to assess the feasibility of translocations within wilderness areas. The potential risks and benefits of using translocation, captive rearing, or artificial propagation as recovery tools should be considered and incorporated into the planning process in order to minimize unintended consequences (Galloway 2014).

\section{CONCLUSION}

This review was conducted in an effort to compile past projects involving the translocation of bull trout Salvelinus confluentus, learn from the successes and failures of these projects, and apply these findings to future translocations of $S$. confluentus. A variety of case studies involving $S$. confluentus translocations within the northwestern USA and southwestern Canada were summarized and analyzed. A secondary review with a broader scope could focus on translocations of other native fishes in the USA or throughout the world in the context of $S$. confluentus reintroductions using translocation. A variety of reviews focused on translocating native fish species have already been completed (Harig et al. 2000, Andrews et al. 2016). While translocation can be a useful tool for the conservation of threatened, endangered, or extirpated populations, it is important to consider its role within the broader context of species conservation. Increased priority should be placed on conserving habitats and extant populations to avoid extirpations and the need for costly reintroductions. This would require the implementation of proactive conservation actions in order to avoid the necessity of retroactive conservation actions including translo- cations. Proactive species conservation would also circumvent the societal factors influencing which species warrant reintroduction and where reintroductions should occur given the changing planet.

Acknowledgements. We thank C. Allen, W. Fredenberg, J. Rasmussen, and M. Taylor for reviews that improved the quality of this article. C. Allen, C. Bienz, W. Fredenberg, B. Matibag, J. Neibauer, T. Whitesel, and N. Zymonas contributed data that enabled the completion of this article. Funding for this work was provided by the USFWS. The findings and conclusions in this article are those of the authors and do not necessarily represent the views of the USFWS.

\section{LITERATURE CITED}

Abell RA, Olsen DM, Dinerstein E, Hurley PT and others (2000) Freshwater ecoregions of North America: a conservation assessment. Island Press, Washington, DC

Adams C, Reisenbichler R, Meyer J (1995) Elwha River ecosystem restoration: potential effects and restoration methods-fisheries investigations. Final report to Olympic National Park, Part I. Inventory of resident fishes in the upper Elwha River. USGS Biological Resources Division, Western Fisheries Research Center, Seattle, WA

Al-Chokhachy R, Budy P (2008) Demographic characteristics, population structure, and vital rates of a fluvial population of bull trout in Oregon. Trans Am Fish Soc 137: 1709-1722

Allan JD, Flecker AS (1993) Biodiversity conservation in running waters. Bioscience 43:32-43

Allen MB, Engle RO, Zendt JS, Shrier FC, Wilson JT, Connolly PJ (2016) Salmon and steelhead in the White Salmon River after the removal of Condit Dam - planning efforts and recolonization results. Trans Am Fish Soc 41:190-203

Andrews TC, Shepard BB, Litt AR, Kruse CG and others (2016) Performance of juvenile cutthroat trout translocated as embryos from five populations into a common habitat. N Am J Fish Manage 36:926-941

Ardren WR, DeHaan PW, Smith CT, Taylor EB and others (2011) Genetic structure, evolutionary history, and conservation units of bull trout in the coterminous United States. Trans Am Fish Soc 140:506-525

Barrows MG, Koch RC, Koshi ML, Bailey E (2016) Clackamas River bull trout reintroduction project, 2015 annual report. USFWS Columbia River Fisheries Program Office, Vancouver, WA

BC Environment (1996) Hill Creek Hatchery \& spawning channel-1995 annual report. Province of British Columbia Ministry of Environment, Lands and Parks, Nelson, BC

* Brenkman SJ, Corbett SC (2005) Extent of anadromy in bull trout and implications for conservation of a threatened species. N Am J Fish Manage 25:1073-1081

Brenkman SJ, Corbett SC, Volk EC (2007) Use of otolith chemistry and radiotelemetry to determine age-specific migratory patterns of anadromous bull trout in the Hoh River, Washington. Trans Am Fish Soc 136:1-11

Brenkman SJ, Pess GR, Torgersen CE, Kloehn KK, Duda JJ, Corbett SC (2008) Predicting recolonization patterns and interactions between potamodromous and anadromous 
salmonids in response to dam removal in the Elwha River, Washington State, USA. Northwest Sci 82:91-106 Brignon WR (2016) Linking moral obligations, assumptionbased research, and structured decision making to inform bull trout recovery. PhD dissertation, Oregon State University, Corvallis, OR

Buchanan D, Hanson ML, Hooton RM (1997) Status of Oregon's bull trout, distribution, life history, limiting factors, management considerations, and status. ODFW, Portland, OR

Buktenica MW, Hering DK, Girdner SF, Mahoney BD, Rosenlund BD (2013) Eradication of nonnative brook trout with electrofishing and antimycin-a and the response of a remnant bull trout population. N Am J Fish Manage 33:117-129

Byrne J, McPeak R, McNamara B (2001) Bull trout population assessment in the Columbia River Gorge. US Department of Energy, Bonneville Power Administration, Portland, OR

Cavender TM (1978) Taxonomy and distribution of bull trout, Salvelinus confluentus (Suckley), from the American Northwest. Calif Fish Game 64:139-174

Clancy C, Decker G, Evarts L, Fredenberg W and others (1995) The role of hatcheries and fish transplants in bull trout recovery. The Montana Bull Trout Restoration Team, Helena, MT

Conley JM (1994) Federal aid in sport fish restoration. Annual fisheries management performance reports 1993. Idaho Fish and Game, Boise, ID

Conley JM (1996) Federal aid in sport fish restoration. Annual fisheries management performance reports 1995. Idaho Fish and Game, Boise, ID

Dambacher JM, Buktenica M, Larson G (1992) Distribution, abundance, and habitat utilization of bull trout and brook trout in Sun Creek, Crater Lake National Park, Oregon. Proceedings of the Gearhart Mountain bull trout workshop. American Fisheries Society, Oregon Chapter, Corvallis, OR, p 30-36

Decker A, Hagen J (2008) Adfluvial bull trout spawner abundance in tributaries to the Arrow Lakes Reservoir (2004-2007). Fish and Wildlife Compensation ProgramColumbia Basin, Nelson, BC

Downs CC, Horan D, Morgan-Harris E, Jakubowski R (2006) Spawning demographics and juvenile dispersal of an adfluvial bull trout population in Trestle Creek, Idaho. N Am J Fish Manag 26:190-200

Downs CC, Fredenberg CR, D'Angelo VS, Muhlfeld CC, McKeon B (2015) Glacier National Park fisheries monitoring and management report, 2014. National Park Service. West Glacier, MT

Nudgeon D, Arthington AH, Gessner MO, Kawabata ZI and others (2006) Freshwater biodiversity: importance, threats, status and conservation challenges. Biol Rev Camb Philos Soc 81:163-182

Dunham JB, Taylor EB, Allendorf FW (2014) Bull trout in the Boundary System - managing connectivity and the feasibility of a reintroduction in the Lower Pend Oreille River, northeastern Washington. Open-File Report 20141229. USGS, Corvallis, OR

Elmberg J, Dessborn L, Englund G (2010) Presence of fish affects lake use and breeding success in ducks. Hydrobiologia 641:215-223

Epanchin PN, Knapp RA, Lawler SP (2010) Nonnative trout impact an alpine nesting bird by altering aquatic insect subsidies. Ecology 91:2406-2415
Evermann BW (1893) A reconnaissance of the streams and lakes of western Montana and northwestern Wyoming. United States Fish Commission, Fort Collins, CO

Fraley JJ, Shepard BB (1989) Life history, ecology, and population status of migratory bull trout (Salvelinus confluentus) in the Flathead Lake and river system, Montana. Northwest Sci 63:133-143

Fredenberg W (1998) Experimental bull trout hatchery progress report two: experimental broodstock development 1995-1997. USFWS, Kalispell, MT

Fredenberg W, Dwyer P, Barrows R (1995) Experimental bull trout hatchery progress report: 1993-1994. USFWS, Kalispell, MT

Galloway BT (2014) Feasibility assessment for translocation of imperiled bull trout populations in Glacier National Park, Montana. Master's thesis, Montana State University, Bozeman, MT

Galloway BT, Muhlfeld CC, Guy CS, Downs CC, Fredenberg WA (2016) A framework for assessing the feasibility of native fish conservation translocations: applications to threatened bull trout. N Am J Fish Manage 36:754-768

* George AL, Kuhajda BR, Williams JD, Cantrell MA, Rakes PL, Shute J (2009) Guidelines for propagation and translocation for freshwater fish conservation. Fisheries 34:529-545

Gilbert CH, Evermann BW (1894) A report upon investigations in the Columbia River basin, with descriptions of four new species of fishes. Bulletin of the US Fish Commission, Washington, DC

GNP, National Parks Conservation Association, USFWS, Flathead Valley Chapter of Trout Unlimited, University of Montana/National Park Service Rocky Mountain Cooperative Ecosystems Study Unit (2003) The case for restoring bull trout in Glacier National Park ... and a framework to do it. National Park Service, West Glacier, MT

Goetz FA (1989) Biology of bull trout, Salvelinus confluentus, a literature review. US Department of Agriculture, Forest Service, Willamette National Forest, Eugene, OR

Goetz FA (1994) Distribution and juvenile ecology of bull trout (Salvelinus confluentus) in the Cascades Mountains. MSc thesis, Oregon State University, Corvallis, OR

Goetz FA, Jeanes E, Beamer E (2004) Bull trout in the nearshore. Preliminary draft report. US Army Corps of Engineers, Seattle, WA

Goodson K, Ackerman N, Gunckel S, Beamesderfer R and others (2005) 2005 Oregon native fish status report. Vol II: assessment methods \& population results. ODFW, Fish Division, Salem, OR

Government of Canada (2016) Species at risk public registry. www.registrelep-sararegistry.gc.ca/sar/index/ default_e.cfm (accessed 20 December 2016)

Harig AL, Fausch KD, Young MK (2000) Factors influencing success of greenback cutthroat trout translocations. N Am J Fish Manage 20:994-1004

Heimer JT (1965) A supplemental Dolly Varden spawning area. MSc thesis, University of Idaho, Moscow, ID

Herrera Environmental Consultants Inc (2013) South Fork Sykomish basin salmon habitat information review and future studies scoping summary report. King County Department of Natural Resources and Parks Water and Land Resources Division, King County, WA, and USDA Forest Service, Seattle, WA

Homel K, Budy P, Pfrender ME, Whitesel TA, Mock K (2008) Evaluating genetic structure among resident and migra- 
tory forms of bull trout (Salvelinus confluentus) in northeast Oregon. Ecol Freshw Fish 17:465-474

Hvenegaard PJ, Thera TM (2001) Monitoring the bull trout (Salvelinus confluentus) spawning run in Lynx Creek, a tributary to the Kakwa River, west central Alberta. Trout Unlimited Canada, Calgary, AB

IDFG (1952) Twenty-fourth biennial report of the Fish and Game Department of the State of Idaho. 1950-1952. IDFG, Boise, ID

Jachowski DS, Millspaugh JJ, Angermeier PL, Slotow R (2016) Reintroduction of fish and wildlife populations. University of California Press, Oakland, CA

James P, Craig S, Shannon J, Eichler T, Anderson E (1998) Evidence of two distinct stocks of bull trout in a central Washington reservoir. North Pacific International Chapter of the American Fisheries Society, Nelson, BC

Janssen PJ, Apperson K, Anderson DR, Patterson J (1997) Federal aid in fish restoration. Regional fishery management investigations. 1994 Job performance report. IDFG, Boise, ID

Jeanes ED, Morello CM (2006) Native char utilization: Lower Chehalis River and Grays Harbor estuary, Aberdeen, Washington. Report prepared by R2 Resource Consultants for US Army Corps of Engineers, Seattle, WA

Jelks HL, Walsh SJ, Burkhead NM, Contreras-Balderas S and others (2008) Conservation status of imperiled North American freshwater and diadromous fishes. Trans Am Fish Soc 33:372-407

Johnston FD, Post JR, Mushens CJ, Stelfox JD, Paul AJ, Lajeunesse B (2007) The demography of recovery of an overexploited bull trout (Salvelinus confluentus) population. Can J Fish Aquat Sci 64:113-126

Klavano WC (1960) Creel census and limnological studies Lake Pend Oreille, 1951 to 1958. Biological and economic survey of fishery resources in Lake Pend Oreille. Idaho Fish and Game, Boise, ID

Leathe S, Graham P (1982) Flathead Lake fish food habits study. Montana Department of Fish, Wildlife and Parks, Kalispell, MT

Littell JS, Mauger GS, Salathe EP, Hamlet AF and others (2014) Uncertainty and extreme events in future climate and hydrologic projections for the Pacific Northwest: providing a basis for vulnerability and core/corridor assessment. Final report for Department of the Interior Pacific Northwest Climate Science Center. Climate Impacts Group, University of Washington, Seattle, WA

Luecke C (1990) Changes in abundance and distribution of benthic macroinvertebrates after introduction of cutthroat trout into a previously fishless lake. Trans Am Fish Soc 119:1010-1021

McPhail JD, Baxter JS (1996) A review of bull trout (Salvelinus confluentus) life-history and habitat use in relation to compensation and improvement opportunities. Fisheries management report no. 104. Department of Zoology, University of British Columbia, Vancouver, BC

Minteer BA, Collins JP (2010) Move it or lose it? The ecological ethics of relocating species under climate change. Ecol Appl 20:1801-1804

Morell V (2008) Into the wild: Reintroduced animals face daunting odds. Science 320:742-743

Mueller JM, Hellmann JJ (2008) An assessment of invasion risk from assisted migration. Conserv Biol 22:562-567

Muhlfeld CC, Giersch JJ, Hauer FR, Pederson GT and others (2011) Climate change links fate of glaciers and an endemic alpine invertebrate. Clim Change 106:337-345
Northwest Power and Conservation Council (2004) White Salmon subbasin plan. The Northwest Power and Conservation Council, Portland, OR

ODFW, USDA Forest Service/Rigdon Ranger District (1998) Rehabilitation of the Middle Fork Willamette bull trout population. Risk analysis and monitoring plan. Oregon Department of Fish and Wildlife, Salem, OR

Patterson S (1992) Sandpoint Fish Hatchery annual report. Idaho Fish and Game, Boise, ID

Pratt KL (1992) A review of bull trout life history. Proceedings of the Gearhart Mountain Bull Trout Workshop. Oregon Chapter of the American Fisheries Society, Corvallis, OR

Pratt KL, Huston JE (1993) Status of bull trout (Salvelinus confluentus) in Lake Pend Oreille and the lower Clark Fork River. Draft report. The Washington Water Power Company, Spokane, WA, p 1-108

Quigley TM, Arbelbide SJ (1997) An assessment of ecosystem components in the interior Columbia basin and portions of the Klamath and Great Basins. USDA Forest Service, Portland, OR

Reiss YK, Thomas J, Anderson E, Cummins J (2012) Yakima bull trout action plan. Yakima Basin Fish and Wildlife Recovery Board, Yakima, WA

Ricciardi A, MacIsaac HJ (2011) Impacts of biological invasions on freshwater ecosystems. In: Richardson, DM (ed) Fifty years of invasion ecology: the legacy of Charles Elton. Blackwell Publishing, Chichester, p 211-224

Ricciardi A, Rasmussen JB (1999) Extinction rates of North American freshwater fauna. Conserv Biol 13:1220-1222

Ricciardi A, Simberloff D (2009) Assisted colonization is not a viable conservation strategy. Trends Ecol Evol 24: 248-253

Rieman BE, McIntyre JD (1993) Demographic and habitat requirements for conservation of bull trout. Gen Tech Rep INT-302. US Forest Service, Intermountain Research Station, Boise, ID

Rieman B, McIntyre J (1996) Spatial and temporal variability in bull trout redd counts. N Am J Fish Manage 16:132-141

Ripple WJ, Estes JA, Beschta RL, Wilmers CC and others (2014) Status and ecological effects of the world's largest carnivores. Science 343:1241484

Rode M (1990) Bull trout, Salvelinus confluentus Suckley, in the McCloud River: status and recovery recommendations. Region 1, inland fisheries. Administrative report no. 90-15. California Department of Fish and Game, Sacramento, CA

Rode M, Dean M (2004) Lower McCloud River wild trout area fishery management plan, 2004 through 2009. California Department of Fish and Game, Sacramento, CA

Schindler D, Parker B (2002) Biological pollutants: alien fishes in mountain lakes. Water Air Soil Pollut Focus 2: 379-397

Shively D, Allen C, Alsbury T, Bergamini B, Goehring B, Horning T, Strobel B (2007) Clackamas River bull trout reintroduction feasibility assessment. USDA Forest Service, Mt. Hood National Forest, USFWS, Oregon State Office, and ODFW, North Willamette Region, Portland, OR

Silver B, Cook J, Hudson JM, Whitesel TA (2009a) White Salmon River bull trout: patches, occupancy and distribution. 2007 progress report. Columbia River Fisheries Program Office, Vancouver, WA

Silver B, Cook J, Hudson JM, Whitesel TA (2009b) White Salmon River bull trout: patches, occupancy and distri- 
bution. 2008 progress report. Columbia River Fisheries Program Office, Vancouver, WA

Silver B, Hudson JM, Whitesel TA (2010) White Salmon River bull trout: patches, occupancy and distribution. 2009 progress report. Columbia River Fisheries Program Office, Vancouver, WA

Silver B, Hudson JM, Whitesel TA (2011) White Salmon River bull trout: patches, occupancy and distribution. 2010 progress report. Columbia River Fisheries Program Office, Vancouver, WA

Snider BR, Thompson B (1993) Annual report: Cabinet Gorge Fish Hatchery. IDFG, Boise, ID

Spruell P, Rieman BE, Knudsed KL, Utter FM, Allendorf FW (1999) Genetic population structure within streams: microsatellite analysis of bull trout populations. Ecol Freshw Fish 8:114-121

Strayer DL (2008) Freshwater mussel ecology: a multifactor approach to distribution and abundance. University of California Press, Berkeley, CA

Strayer DL, Dudgeon D (2010) Freshwater biodiversity conservation: recent progress and future challenges. J N Am Benthol Soc 29:344-358

Taylor G (2000) Bull trout (Salvelinus confluentus) population and habitat surveys in the Middle Fork Willamette and McKenzie basin, 2000. Project no. 1994-05300. Bonneville Power Administration, Portland, OR

Thiesfeld SL, McPeak RH, McNamara BS (2001) 2001 annual report-Washington Department of Fish and Wildlife. Bull trout population assessment in the White Salmon and Klickitat rivers, Columbia River Gorge, Washington. Bonneville Power Administration, Portland, OR

Tranquilli VJ, Helms CK, Wade MG (2005) Middle Fork Willamette basin bull trout rehabilitation and monitoring project-October 2004 through September 2005. ODFW, Springfield, OR

US Department of the Interior Bureau of Reclamation, State of Washington Department of Ecology (2014) Bull trout enhancement Kachess drought relief pumping plant and Keechelus-to-Kachess conveyance, Kittitas and Yakima Counties, Washington. A component of the Yakima River basin integrated water resource management plan. Bureau of Reclamation, Yakima, WA

USFWS (US Fish and Wildlife Service) (2002a) Middle Columbia recovery unit, Washington. In: U.S. Fish and Wildlife Service bull trout (Salvelinus confluentus) draft recovery plan, Chapter 21. USFWS, Portland, OR, p 1-86

USFWS (2002b) Willamette River recovery unit, Oregon. In: US Fish and Wildlife Service bull trout (Salvelinus confluentus) draft recovery plan, Chapter 5. USFWS, Portland, OR, p 1-96

USFWS (2005) Bull trout core area templates-complete core area by core area analysis. USFWS, Portland, Oregon

USFWS (2009) Endangered and threatened wildlife and plans; establishment of a nonessential experimental population of bull trout in the Clackamas River subbasin, Oregon. Federal Register. Vol 74, no. 235. Proposed rules. USFWS, Arlington, VA, p 65045-65055

USFWS (2011) Clackamas River bull trout reintroduction implementation, monitoring, and evaluation plan. USFWS, Portland, OR

USFWS (2015a) Recovery plan for the coterminous United
States population of bull trout (Salvelinus confluentus). USFWS, Portland, OR

USFWS (2015b) 5-year review short form summary. USFWS, Boise, ID

USFWS (2015c) Klamath recovery unit implementation plan for bull trout (Salvelinus confluentus). USFWS, Klamath Falls, OR

USFWS (2015d) Coastal recovery unit implementation plan for bull trout (Salvelinus confluentus). USFWS, Portland, OR

USFWS (2015e) Columbia headwaters recovery unit implementation plan for bull trout recovery plan. USFWS, Kalispell, MT

UWBTWG (Upper Willamette Bull Trout Working Group) (2007) Status of bull trout (Salvelinus confluentus) in the Middle Fork Willamette basin ten years after implementation of a rehabilitation plan. ODFW, Springfield, OR

UWBTWG (2010) Upper Willamette basin bull trout action plan 2010. ODFW, USFS, US Army Corps of Engineers, USFWS, and Eugene Water and Electric Board, Corvallis, OR

Wallis OL (1948) Trout studies and a stream survey of Crater Lake National Park. MSc thesis, Oregon State University, Corvallis, OR

Ward L, Crain P, Freymond B, McHenry M and others (2008) Elwha River fish restoration plan-developed pursuant to the Elwha River ecosystem and fisheries restoration act, public law 102-495. NOAA Tech Memo NMFSNWFSC-90. U.S. Department of Commerce, Seattle, WA

Washington Department of Fisheries (1975) A catalog of Washington streams and salmon utilization. WDF, Seattle, WA

WDFW (Washington Department of Fish and Wildlife) (2004) Washington State salmonid stock inventory: bull trout/Dolly Varden. WDFW, Olympia, WA

WDFW (2016) DNS 16-031: Sunset Falls fish release site relocation. WDFW, Olympia, WA

WDFW, FishPro Incorporated, Beak Consultants Incorporated (1997) Grandy Creek trout hatchery biological assessment. Washington Department of Fish and Wildlife, Olympia, WA

Whitesel TA, DeHaan P, Doyle J, Adams B (2015a) Were bull trout successfully reintroduced into the Wallowa River? USFWS, Vancouver, WA

Whitesel TA, DeHaan P, Doyle J, Adams B (2015b) Were bull trout successfully reintroduced into the Wallowa River? American Fisheries Society. https://afs.confex.com/afs/ 2015/webprogram/Paper20595.html (accessed 1 December 2016)

Williams JE, Sada DW, Williams CD (1988) American Fisheries Society guidelines for introductions of threatened and endangered fishes. Trans Am Fish Soc 13:5-11

Zymonas ND (2011) Re-introduction of bull trout in the Upper Willamette River basin, USA. In: Soorae PS (ed) Global re-introduction perspectives: 2011. More case studies from around the globe. IUCN/SSC Re-introduction Specialist Group, Gland, and UAE Environment Agency, Abu Dhabi, p 44-48

Zymonas ND, Tranquilli V (2012) Middle Fork Willamette basin bull trout rehabilitation and monitoring project October 2006-February 2010. US Army Corps of Engineers Portland District-Willamette Valley Project, Corvallis, OR 